\title{
Risk Perception, Gender, dan Pengetahuan Investasi pada Niat Berinvestasi
}

\author{
Luh Gede Krisna Dewi ${ }^{1}$ \\ Fakultas Ekonomi dan Bisnis \\ Universitas Udayana, Indonesia
}

\author{
Made Yeni Latrini ${ }^{2}$ \\ Fakultas Ekonomi dan Bisnis \\ Universitas Udayana, Indonesia
}

\section{Made Dwi Budiana Penindra ${ }^{3}$ Fakultas Teknik Universitas Udayana, Indonesia}

\begin{abstract}
Surel : gede_krisna@unud.ac.id
ABSTRAK

Penelitian bertujuan untuk menganalisis pengaruh risk perception, gender, dan pengetahuan investasi pada niat berinvestasi mahasiswa akuntansi. Penelitian di lakukan pada Universitas/Politeknik/Sekolah Tinggi Negeri dan Swasta Provinsi Bali dengan jumlah sampel 270 mahasiswa. Metode penyampelan menggunakan metode purposive sampling. Teknik analisis yang digunakan adalah regresi linear berganda dengan menggunakan instrumen kuesioner. Hasil penelitian menunjukan risk perception dan pengetahuan investasi berpengaruh positif sedangkan gender berpengaruh negatif pada niat berinvestasi mahasiswa akutansi. Implikasi penelitian ini mendukung Theory of Planned Behavior yang menyebutkan bahwa aspek personal, sosial dan informasi membentuk sikap, norma subyektif, persepsi kontrol dalam mendorong niat berinvestasi mahasiswa akuntansi. Implikasi praktis penelitian bagi institusi pendidikan untuk mengembangkan pendidikan dalam bidang investasi.
\end{abstract}

Kata Kunci: Risk Perception; Gender; Pengetahuan Investasi; Niat Berinvetasi.

\section{Risk Perception, Gender, and Investment Knowledge on Investment Intention}

\section{ABSTRACT}

This study aims to analyze the effect of risk perception, gender, and investment knowledge on the investment intentions of accounting students. The research was conducted at Universities/Polytechnics/ State and Private Colleges of Bali Province with a total sample of 270 students. Sampling method using purposive sampling method. The analysis technique used is multiple linear regression using a questionnaire instrument. The results showed that risk perception and investment knowledge had a positive effect while gender had a negative effect on the investment intentions of accounting students. The implication of this research supports the Theory of Planned Behavior which states that personal, social and informational aspects shape attitudes, subjective norms, perceptions of control in encouraging accounting students' investment intentions. Practical implications of research for educational institutions to develop education in the field of investment.

Keywords: Risk Perception; Gender; Investment Knowledge; Intention to Invest.

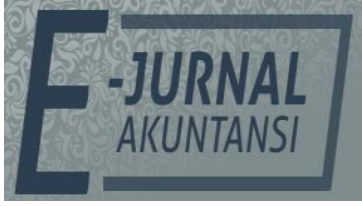

e-ISSN 2302-8556

Vol. 31 No. 11

Denpasar, November 2021

Hal. 2912-2922

DOI:

10.24843/EJA.2021.v31.i11.p18

PENGUTIPAN:

Dewi, L.G.K.,Latrini, M.Y., \& Penindra, I.M.D.B. (2021). Risk Perception, Gender, dan Pengetahuan Investasi pada Niat Berinvestasi. E-Jurnal Akuntansi, 31(11), 2912-2922

RIWAYAT ARTIKEL:

Artikel Masuk:

14 Januari 2021 Artikel Diterima: 28 Desember 2021

Artikel dapat diakses : https://ojs.unud.ac.id/index.php/Akuntansi/index 


\section{PENDAHULUAN}

Perkembangan iklim investasi di Indonesia saat ini sangat menjanjikan. Pemerintah melalui Bursa Efek Indonesia (BEI) dan Otoritas Jasa Keuangan (OJK) memberikan peluang untuk bertumbuhnya investasi dan mendorong individu untuk melakukan investasi. Kemudahan dalam berinvestasi difasilitasi dengan keberadaan pasar modal yang semakin menawarkan jenis investasi yang menarik bagi calon investor. Melalui pasar modal pihak yang membutuhkan dana jangka panjang akan dipertemukan dengan pihak yang membutuhkan sarana untuk berinvestasi seperti saham, obligasi, reksadana dan lainnya. Pemerintah melakukan Kampanye Yuk Nabung Saham (YNS) sejak tahun 2015 bertujuan mendorong masyarakat untuk mengubah kebiasaan dari saving society menjadi investing society. Perguruan Tinggi beserta Otoritas Jasa Keuangan berperan dalam memberikan wawasan dan kesempatan berinvestasi bagi mahasiswa melalui Galeri Investasi. Pembentukan wadah ini dapat mendorong minat civitas akademika untuk berinvestasi.

Minat adalah kecondongan yang menetap pada subjek guna merasa senang maupun berketertarikan dengan bidang atau perihal tertentu, serta gemar bersinggungan dengan bidang tersebut (Winkel, 1983). Minat berinvestasi adalah kecenderungan individu melakukan investasi dengan pertimbangan memperoleh keuntungan di masa yang akan datang (Sriatun \& Indarto, 2017). Minat berinvestasi pada individu mendorong mereka melakukan tindakan yang mendukung kegiatan investasi seperti mengikuti pelatihan investasi, bergabung dengan kelompok investasi dan pada akhirnya melakukan investasi. Individu dapat merencanakan tindakan yang mendukung minat berinvestasi.

Theory of Planned Behavior (TPB) merupakan salah satu teori psikologi sosial yang memprediksi perilaku manusia, memahami cara seseorang dalam bersikap, serta upaya memperlihatkan dan dipergunakan dalam menjelaskan perilaku apa pun yang membutuhkan rencana (Fishbein \& Ajzen, 1991). Berdasarkan teori ini proses pembelajaran adalah hasil dari pengalaman individu dalam interaksi dengan lingkungannya yang menyangkut kognitif, afektif dan psikomotorik tersebut sehingga menyebabkan suatu perubahan tingkah laku. Teori ini menjelaskan tentang sudut pandang kepercayaan melalui penggabungan beraneka ragam karakteristik, kualitas dan atribut atas informasi, yang mampu mempengaruhi seseorang untuk melaksanakan tingkah laku yang spesifik. Theory of Planned Behavior menjelaskan niat (intention) untuk melakukan tindakan dipengaruhi oleh sikap, norma-norma subyektif, dan persepsi pengendalian perilaku. Sementara faktor yang berperan membentuk sikap, norma dan persepsi kontrol perilaku adalah pertama, aspek personal meliputi sikap secara umum, kepribadian, nilai-nilai yang diyakini, emosi, dan intelektual. Kedua, aspek sosial meliputi usia, gender, pendidikan, pendapatan dan agama. Ketiga, aspek informasi meliputi pengalaman, pengetahuan, dan media (Fishbein \& Ajzen, 1991).

Riset terdahulu Nurhidayah, (2016), Dewi et al., (2017), Dina, (2009), Hamonangan, (2007), Pompian \& Longo, (2004), Weber et al., (2002) menemukan bahwa faktor-faktor sosial seperti gender, pendapatan, pengetahuan, serta faktor psikologis/emosional seperti persepsi risiko, risk attitude, dan self-control dapat mempengaruhi niat berinvestasi saham bagi investor individu. Investor 
mempunyai respon terhadap informasi yang diperoleh tetapi mempunyai kemampuan kognitif terbatas dalam menginterpretasikan informasi yang diterima, sehingga investor kadang bertindak tidak rasional. Kondisi keterbatasan ini disebut bounded rationality. Konsep rasionalitas investor mendapat tanggapan yang beragam, baik dari kalangan praktisi maupun akademisi karena selain faktor kognitif yang terbatas, terdapat juga faktor psikologi yang memengaruhi manusia (Pompian \& Longo, 2004). Dengan demikian perilaku rasional tidak selalu terjadi di pasar modal karena selengkap apapun informasi yang dimiliki investor pasti melibatkan aspek sosial dan personal dalam proses pengambilan keputusan, yaitu aspek emosi, seperti overconfidence bias, loss-aversion bias, status quo bias, dan endowment bias (Mokhtar, 2014), aspek demografi yaitu gender, sophistication, usia, profesi, dan pengalaman (Prosad et al., 2015).

Persepsi (perception) sebagai sudut pandang dari seseorang selama memahami objek atau kejadian melalui pancaindera, didapat melalui pengalaman perihal objek secara subjektif maupun kondisional, sehingga berbeda dengan sudut pandang orang lain atas objek yang serupa (Balai Pustaka, 1995). Risk perception berpengertian sebagai keuntungan yang menyimpang, atau tidak sesuai harapan (Weston \& Copeland, 1995). Melalui kehadiran ketidakpastian, maka pemodal bisa mendapat pengembalian pada periode berikutnya yang belum mengetahui secara pasti nilai yang didapat (Hartono, 2010).

Gender merupakan kedudukan, fungsi, pertanggungjawaban, maupun pengklasifikasian kelas dibanding pria dan wanita atas penetapan dari masyarakat yang berdasar pada sifat wanita maupun pria yang diasumsikan layak sesuai norma, adat, ataupun kepercayaan masyarakat (Utaminingsih, 2017). Masyarakat membeda-bedakan antara laki-laki dengan perempuan agar bisa merancang ekspetasi sosial yang menetapkan perilaku atau sikap yang sesuai dengan jenis kelamin masing-masing. Perihal itu pun menetapkan perbedaan dari hak maupun akses atas kedudukan di dalam masyarakat, kepemilikan, ataupun kesehatan. Konsep gender lebih menekankan pada perbedaan ciri-ciri peran dan tanggung jawab, bukan pada perbedaan jenis kelamin (biologis) (Utaminingsih, 2017).

Peningkatan minat berinvestasi saham di pasar modal salah satunya didorong oleh edukasi investasi. Pengetahuan investasi yang memadai dimiliki oleh seseorang dalam memaksimalkan rasa percaya pada diri mereka terhadap perihal itu, yaitu investasi saham. (Hurlock, 1999) menuturkan minat pada diri seseorang bisa muncul melalui pemberian kesempatan untuk orang itu guna belajar terkait sesuatu yang mereka kehendaki. Pelatihan investasi termasuk instrumen investasi memberikan pengetahuan kepada individu sehinga mendorong minat berinvestasi.

Penelitian ini menguji pengaruh risk perception, gender dan pengetahuan investasi pada minat mahasiswa untuk melakukan investasi khususnya investasi jangka panjang seperti saham, obligasi dan reksadana. Risk perception, gender dan pengetahuan investasi merupakan proksi dari aspek personal, sosial dan informasi yang mendukung niat (intention) individu dalam melakukan investasi. Temuan penelitian ini mendukung Theory of Planned Behavior yang menyebutkan bahwa aspek personal, sosial dan informasi membentuk sikap, norma subyektif, persepsi kontrol dalam mendorong niat berinvestasi mahasiswa akuntansi. Secara 
praktis, hasil penelitian menjadi referensi dalam perbaikan pola pembelajaran mahasiswa akuntansi terkait dengan bidang investasi. Mahasiswa sebagai calon investor muda diharapkan dapat menjadi motor penggerak perubahan dari saving society menjadi investing society.

Risiko merupakan faktor yang umumnya ditakuti dan tidak disukai oleh setiap orang, termasuk investor. Perbedaannya hanya pada seberapa besar setiap orang mampu menerima atau menoleransi risiko. Hartono (2010) menyatakan bahwa dalam berinvestasi individu perlu mempertimbangkan risiko selain return. Risiko merupakan trade-off return yang perlu dipertimbangkan selama berinvestasi. Penelitian (Yuwono, 2011) memperlihatkan bila sudut pandang terkait risiko adalah faktor yang memengaruhi keinginan berinvestasi. Investor yang siap menerima risiko yang lebih besar memiliki kemungkinan yang lebih besar berinvestasi saham (Warneryard, 2001).

$\mathrm{H}_{1}$ : Risk perception berpengaruh positif pada niat berinvestasi mahasiswa akuntansi.

Faktor perbedaan gender yang memengaruhi niat berinvestasi dan transaksi telah diteliti di banyak negara dengan hasil yang belum konklusif. Temuan yang menunjang hubungan gender dengan keputusan berinvestasi adalah pemodal berjenis kelamin pria lebih aktif bertransaksi dibandingkan wanita, terutama transaksi pembelian (Pompian \& Longo, 2004). (Bogan et al., 2013) melakukan penelitian terkait pengaruh perbedaan gender terhadap perilaku dalam keputusan investasi, dan memperoleh bukti bila pemodal pria meningkatkan peluang berinvestasi yang berisiko lebih tinggi, semisal saham. Hasil penemuan itu sesuai dengan penjelasan (Tauni et al., 2017) memaparkan bahwa investor laki-laki memiliki kemungkinan lebih sering melakukan perdagangan saham dibandingkan perempuan.

$\mathrm{H}_{2}$ : Gender berpengaruh pada niat berinvestasi mahasiswa akuntansi.

Pengetahuan investasi adalah pemahaman seseorang terkait beragam aspek investasi, seperti pengetahuan dasar penilaian investasi, peluang risiko, maupun tingkat pengembalian (return) investasi (Halim, 2005). Pengetahuan dasar investasi berperan krusial bagi calon investor, untuk menghindarkan dari praktik investasi yang tidak rasional (perjudian), berinvestasi akibat ikut-ikutan saja (herding), tindakan penipuan, maupun risiko kerugian. Ketercukupan pengetahuan, pengalaman, dan naluri bisnis diperlukan dalam melakukan investasi di pasar modal dan mengkaji efek mana pun yang hendak dibeli (Halim, 2005:4). Pengetahuan tentang berinvestasi akseptabel di pasar modal, seperti pada instrumen investasi saham. Penelitian terdahulu oleh (Hamonangan, 2007) dan (Wiwin, 2006) menunjukkan bahwa pengetahuan berinvestasi berpengaruh positif pada niat melakukan investasi pada mahasiswa.

$\mathrm{H}_{3}$ : Pengetahuan investasi berpengaruh positif pada niat berinvestasi mahasiswa akuntansi. 


\section{METODE PENELITIAN}

Penelitian ini dilakukan di tujuh Universitas dan satu Politeknik/Sekolah Tinggi negeri maupun swasta yang ada di Bali. Populasi dalam penelitian ini adalah mahasiswa akuntansi yang masih berstatus aktif. Mahasiswa akuntansi dipilih sebagai responden penelitian karena keberadaan mereka sebagai calon yang profesional di bidang akuntansi maupun finansial, serta diharapkan memiliki pengetahuan investasi memadai. Proses memperoleh sampel (sampling) dari populasi yang tersedia dilaksanakan secara purposive sampling. Metode ini bertujuan memperoleh sampel yang tepat dan berdasar para ketentuan. Kriteria yang ditentukan dalam pemilihan sampel ini adalah mahasiswa akuntansi yang telah menempuh dan lulus mata kuliah Teori Pasar Modal dan Manajemen Keuangan. Penggunaan Google Form untuk memperoleh respon dari responden dilakukan mengingat penelitian ini dilakukan saat situasi pandemi. Penyebaran form pada delapan Universitas/Politeknik/Sekolah Tinggi menetapkan batas waktu selama tiga minggu, sehingga diperoleh respon sebesar 281 kuesioner terisi. Proses penentuan sampel nampak pada Tabel 1. Hasil Seleksi Pemilihan Sampel.

Teknik analisis data yang digunakan dalam penelitian ini adalah analisis regersi linear berganda yang bertujuan memperoleh gambaran mengenai pengaruh variabel independen pada variabel dependen. Data dianalisis menggunakan SPSS melalui uji asumsi klasik, uji statistik deskriptif, uji koefisien determinasi (uji F), dan uji hipotesis (uji t). Variabel bebas dalam penelitian ini adalah risk perception $\left(X_{1}\right)$, gender $\left(X_{2}\right)$, dan pengetahuan investasi $\left(X_{3}\right)$. Untuk variabel terikat adalah niat berinvestasi $(Y)$.

Sudut pandang cenderung bersifat subjektif dan kondisional, sehingga ada perbedaan dengan sudut pandang dari orang lain terkait objek yang serupa (Balai Pustaka, 1995). Risk perception merupakan keuntungan yang menyimpang dari harapan (Weston \& Copeland, 1995). Risk perception adalah trade-off antara manfaat yang diharapkan dari sebuah pilihan investasi dengan risikonya (Weber et al., 2002). Untuk mengukur risk perception adalah dengan menggunakan risk perception scale bidang investasi dari penelitian (Weber et al., 2002), dengan 4 pernyataan mempergunakan skala Likert 5 poin dengan nilai paling rendah untuk $1=$ sangat tidak mungkin dan 5 = sangat mungkin. Skala ini menunjukkan tingkat risk perception individu, semakin rendah skor menunjukkan persepsi terhadap risiko semakin besar (cenderung risk averse) dan sebaliknya semakin tinggi skor menunjukkan persepsi terhadap risiko semakin rendah (cenderung risk seeker).

Gender adalah atribut, perilaku, kriteria dan ekspektasi yang terkait perbedaan peran antara laki-laki dan perempuan dalam kebudayaan yang berlaku. Gender dalam penelitian ini dikaitkan dengan perbedaan peran perempuan dan laki-laki. Pengukuran variabel gender menggunakan teknik dummy variabel dimana untuk laki-laki diberikan kode "1" dan perempuan dengan kode " 0 ".

Pengetahuan investasi merupakan pemahaman mengenai investasi yakni pengetahuan dasar penilaian investasi, tingkat risiko, maupun tingkat pengembalian investasi yang dimiliki seseorang. Variabel ini diukur dengan menggunakan instrumen yang diadopsi dan dikembangkan dari penelitian (Kusmawati, 2011). Indikator pengukuran pengetahuan investasi, yaitu pemahaman terkait situasi berinvestasi, pengetahuan mendasar mengenai 
penilaian saham, tingkat risikonya, dan tingkat pengembalian investasi. Variabel ini di ukur menggunakan skala Likert 5 poin.

Niat berinvestasi ialah kehendak pada diri individu guna mempelajari beragam hal terkait pemodalan sampai ke praktik berinvestasi. Variabel terikat adalah niat berinvestasi, dengan item pertanyaan 5 item pernyataan yang mengukur tingkat intensi (intention) mahasiswa melakukan investasi. Variabel diukur dengan menggunakan skal Likert 5 poin dan merujuk penelitian terdahulu dari (Kusmawati, 2011) dan Winantyo (2017).

$Y=\alpha+\beta_{1} X_{1}+\beta_{2} X_{2}+\beta_{3} X_{3}+\beta_{4} X_{4}+\beta_{5} X_{5}+\varepsilon$

\section{HASIL DAN PEMBAHASAN}

Data penelitian dikumpulkan dengan menyebarkan instrumen ke delapan Universitas, Politeknik dan Sekolah Tinggi Negeri dan Swasta yang ada di Bali. Tabel 1, menunjukkan hasil pemilihan sampel penelitian berdasarkan kriteria yang telah ditetapkan sebelumnya.

Tabel 1. Hasil Seleksi Pemilihan Sampel

\begin{tabular}{ll}
\hline Keterangan & Jumlah \\
\hline Kuesioner terisi & 281 \\
Kuesioner yang tidak sesuai kriteria & $(11)$ \\
Kuisoner yang dapat digunakan & 270 \\
Tingkat usable response rate & $96,09 \%$ \\
\hline
\end{tabular}

Sumber: Data Penelitian, 2020

Tingkat usable response rate penelitian ini tinggi yakni 96,09 persen, hanya ada 11 kuesioner yang tidak dapat digunakan karena responden tidak sesuai dengan kriteria sampel dan tidak lengkap dalam mengisi jawaban kuesioner. Selanjutnya karakteristik responden dilihat dari usia, jenis kelamin dan asal institusi diuraikan dalam Tabel 2 dan pembahasan berikut.

Tabel 2. Karakteristik Usia Responden

\begin{tabular}{cccccc}
\hline & & Frequency & Percent & $\begin{array}{c}\text { Valid } \\
\text { Percent }\end{array}$ & $\begin{array}{c}\text { Cumulative } \\
\text { Percent }\end{array}$ \\
\hline Valid & $18-22$ & 252 & 93,3 & 93,3 & 93,3 \\
& $23-27$ & 14 & 5,2 & 5,2 & 98,5 \\
& $28-33$ & 4 & 1,5 & 1,5 & 100,0 \\
& Total & 270 & 100,0 & 100,0 & \\
\hline
\end{tabular}

Sumber: Data Penelitian, 2020

Dilihat dari struktur jenis kelamin, kelompok responden perempuan dominan dalam pengisian kuesioner ini. Sebanyak 79,6 persen responden perempuan mengisi kuesioner, sisanya sebanyak 20,4 persen responden merupakan laki-laki.

Tabel 3. Karakteristik Jenis Kelamin Responden

\begin{tabular}{llcccc}
\hline & & & Valid & Cumulative \\
& & Frequency & Percent & Percent & Percent \\
\hline Valid & L & 55 & 20,4 & 20,4 & 20,4 \\
& P & 215 & 79,6 & 79,6 & 100,0 \\
& Total & 270 & 100,0 & 100,0 & \\
\hline
\end{tabular}

Sumber: Data Penelitian, 2020

Informasi mengenai institusi asal responden juga dapat kita lihat dari hasil frekuensi ini. Berdasarkan data yang dikumpulkan, responden berasal dari 
Universitas/Politeknik/Sekolah Tinggi Negeri sebanyak 19,6 persen dan sebanyak 80,4 persen responden merupakan mahasiswa Universitas/Politeknik/Sekolah Tinggi Swasta. Jika dilihat dari jenis institusi asal responden, mayoritas berasal dari Universitas (93,7 persen) dan hanya 6,3 persen yang berasal dari Politeknik/Sekolah Tinggi.

Tabel 4. Hasil Statistik Deskriptif

\begin{tabular}{lccccc}
\hline & $N$ & Minimum & Maksimum & Rata-rata & $\begin{array}{c}\text { Standar } \\
\text { deviasi }\end{array}$ \\
\hline Niat berinvestasi & 270 & 1,63 & 5,00 & 4,186 & 0,599 \\
Risk perception & 270 & 1,00 & 5,00 & 2,680 & 0,701 \\
Gender & 270 & 0,00 & 1,00 & 0,204 & 0,404 \\
Pengetahuan investasi & 270 & 1,50 & 5,00 & 4,496 & 0,560 \\
Valid N (listwise) & 270 & & & & \\
\hline
\end{tabular}

Sumber: Data Penelitian, 2020

Berdasar Tabel 4, memperjelas bila variabel niat berinvestasi memiliki nilai minimum sejumlah 1,63; nilai maksimum sejumlah 5,00 nilai rerata (mean) sejumlah 4,186 dan berstandar deviasi sejumlah 0,599. Nilai rerata apabila dibulatkan mendekati angka 4 artinya responden rata-rata memberikan jawaban setuju atas pernyataan kuesioner.

Pada variabel risk perception nilai minimum adalah 1,00; nilai maksimum sejumlah 5,00; nilai rerata (mean) sejumlah 2,680, dan berstandar deviasi sejumlah 0,700 . Nilai rerata apabila dibulatkan mendekati angka 3 artinya responden ratarata memberikan jawaban netral atas pernyataan kuesioner.

Pada variabel pengetahuan investasi nilai minimum adalah 1,50; nilai maksimum sejumlah 5,00; nilai rerata (mean) sejumlah 4,495, sedangkan standar deviasi sejumlah 0,560. Nilai rerata apabila dibulatkan mendekati angka 5 artinya responden rata-rata memberikan jawaban sangat setuju atas pernyataan kuesioner Tabel 5. Hasil Uji Normalitas

\begin{tabular}{ll}
\hline & Unstandardized Residual \\
\hline $\mathrm{N}$ & 270 \\
Asymp. Sig. (2-tailed) & 0,200 \\
\hline
\end{tabular}

Sumber: Data Penelitian, 2020

Berdasar uji normalitas, memperlihatkan bila tabel one-sample kolmogorovsmirnov test lebih dari nilai Asymp. Sig. (2-tailed) yakni 0,200, atau menjelaskan jika data itu bernilai Asymp. Sig. (2-tailed) lebih dari 0,05 maka menyimpulkan bila data yang dipergunakan pada penelitian dianggap terdistribusi secara normal.

Tabel 6. Hasil Uji Heterokedastisitas

\begin{tabular}{|c|c|c|c|c|c|c|}
\hline \multirow{2}{*}{\multicolumn{2}{|c|}{ Model }} & \multicolumn{2}{|c|}{$\begin{array}{c}\text { Unstandardized } \\
\text { Coefficients }\end{array}$} & \multirow{3}{*}{$\begin{array}{c}\text { Standardized } \\
\text { Coefficients } \\
\text { Beta }\end{array}$} & \multirow[b]{3}{*}{$\mathrm{t}$} & \multirow[b]{3}{*}{ Sig. } \\
\hline & & & Std. & & & \\
\hline & & B & Error & & & \\
\hline \multirow[t]{4}{*}{1} & (Constant) & 0,463 & 0,162 & & 2,851 & 0,005 \\
\hline & Risk perception & $-0,019$ & 0,027 & $-0,044$ & $-0,711$ & 0,478 \\
\hline & Gender & 0,068 & 0,046 & 0,091 & 1,481 & 0,140 \\
\hline & Pengetahuan investasi & $-0,013$ & 0,033 & $-0,024$ & $-0,398$ & 0,691 \\
\hline
\end{tabular}

Sumber: Data Penelitian, 2020

Berdasar hasil pengujian Glejser yang sudah disampaikan, memperlihatkan bila nilai signifikansi di atas 0,05 , atau tanpa ada 
heteroskedastisitas. Hasil pengujian Glejser memperlihatkan hasil p signifikansi lebih dari 0,05, maka menyimpulkan bila tanpa adanya heteroskedastisitas.

Tabel 7. Hasil Uji Multikolinearitas

\begin{tabular}{|c|c|c|c|c|c|c|c|c|}
\hline \multirow{3}{*}{ Model } & & \multicolumn{2}{|c|}{$\begin{array}{l}\text { Unstandardized } \\
\text { Coefficients }\end{array}$} & \multirow{3}{*}{$\begin{array}{c}\begin{array}{c}\text { Standardized } \\
\text { Coefficients }\end{array} \\
\text { Beta }\end{array}$} & \multirow[b]{3}{*}{$t$} & \multirow[b]{3}{*}{ Sig. } & \multicolumn{2}{|c|}{$\begin{array}{c}\text { Collinearity } \\
\text { Statistics }\end{array}$} \\
\hline & & & Std. & & & & & \\
\hline & & B & Error & & & & Tolerance & VIF \\
\hline \multirow[t]{4}{*}{$\overline{1}$} & (Constant) & 1,118 & 0,256 & & 4,375 & 0,000 & & \\
\hline & rception & 0,133 & 0,042 & 0,156 & 3,177 & 0,002 & 0,989 & 1,011 \\
\hline & Gender & $-0,215$ & 0,073 & $-0,145$ & $-2,956$ & 0,003 & 0,987 & 1,013 \\
\hline & $\begin{array}{l}\text { Pengetahuan } \\
\text { investasi }\end{array}$ & 0,613 & 0,052 & 0,573 & 11,695 & 0,000 & 0,991 & 1,009 \\
\hline
\end{tabular}

Sumber: Data Penelitian, 2020

Sesuai uraian tersebut, menyimpulkan bila tolerance variabel bebas pada data di kajian ini di atas 0,10 sedangkan VIF variabel terikat di bawah 10. Hasil itu menyimpulkan bila variabel independen tanpa berhubungan secara bermakna. Hasil uji ini memperlihatkan bila analisis data sesuai dengan asumsi multikolinearitas.

\section{Tabel 8. Hasil Pengujian Koefisien Determinasi (Adj R²)}

\begin{tabular}{lcccc}
\hline Model & $\mathrm{R}$ & $\mathrm{R}$ Square & $\begin{array}{c}\text { Adjusted } \mathrm{R} \\
\text { Square }\end{array}$ & $\begin{array}{c}\text { Std. Error of } \\
\text { the Estimate }\end{array}$ \\
\hline 1 & $0,607^{\mathrm{a}}$ & 0,368 & 0,361 & 0,479 \\
\hline Sumber: Data Penelitian, 2020 & & &
\end{tabular}

Sesuai uraian tersebut, menyimpulkan bila nilai Adjusted R-Square sejumlah 0,361 . Perihal ini memperlihatkan bila variabel bebas bisa memperjelas variabel terikat sejumlah 36,1 persen sedangkan tersisa 63,9 persen variabel terikat diperjelas oleh variabel lainnya yang tidak dimodelkan pada kajian ini.

Tabel 9. Hasil Uji Simultan (Uji F)

\begin{tabular}{llrrrrl}
\hline & & Sum of & \multicolumn{3}{c}{ Mean } \\
Model & & Squares & df & Square & \multicolumn{1}{c}{$F$} & \multicolumn{1}{c}{ Sig. } \\
\hline 1 & Regression & 35,574 & 3 & 11,858 & 51,645 & $0,000^{\mathrm{b}}$ \\
& Residual & 61,074 & 266 & 0,230 & & \\
& Total & 96,648 & 269 & & & \\
\hline
\end{tabular}

Sumber: Data Penelitian, 2020

Sesuai uraian tersebut, menyimpulkan bila hasil uji statistik $F$ memperlihatkan nilai $F$ sejumlah 51,645 signifikan sejumlah 0,000. Nilai signifikansi yang lebih kecil dibanding nilai 0,05 berarti keseluruhan variabel independen mempengaruhi variabel dependen, atau model layak dipergunakan.

\section{Tabel 10. Hasil Uji Parsial (Uji t)}

\begin{tabular}{|c|c|c|c|c|c|c|}
\hline \multirow{3}{*}{ Model } & & $\begin{array}{l}\text { Unstandardized } \\
\text { Coefficients }\end{array}$ & & $\begin{array}{l}\text { indardized } \\
\text { Defficients }\end{array}$ & \multirow[b]{3}{*}{$\mathrm{t}$} & \multirow[b]{3}{*}{ Sig. } \\
\hline & & \multirow[b]{2}{*}{ B } & \multicolumn{2}{|l|}{ Std. } & & \\
\hline & & & Error & Beta & & \\
\hline 1 & (Constant) & 1,118 & 0,256 & & 4,375 & 0,000 \\
\hline & Risk perception & 0,133 & 0,042 & 0,156 & 3,177 & 0,002 \\
\hline & Gender & $-0,215$ & 0,073 & $-0,145$ & $-2,956$ & 0,003 \\
\hline & $\begin{array}{l}\text { Pengetahuan } \\
\text { investasi }\end{array}$ & 0,613 & 0,052 & 0,573 & 11,695 & 0,000 \\
\hline
\end{tabular}

Sumber: Data Penelitian, 2020 
Berdasarkan Tabel 10, diperoleh persamaan regresi yang dihasilkan dari pengujian tersebut adalah seperti berikut ini.

$$
\mathrm{Y}=1,118+0,133 \mathrm{X}_{1}-0,215 \mathrm{X}_{2}+0,613 \mathrm{X}_{3}
$$

Nilai konstanta sebesar 1,118 artinya jika variabel risk perception, gender, dan pengetahuan investasi sama dengan nol, maka nilai niat berinvestasi mahasiswa sama dengan 1,118. Nilai koefisien regresi X1 sebesar 0,133 artinya jika risk perception mengalami peningkatan sebesar satu satuan dengan asumsi gender dan pengetahuan investasi dianggap tetap, maka niat berinvestasi mahasiswa mengalami peningkatan sejumlah 0,133. Hasil pengujian menunjukkan variabel risk perception memiliki t hitung sebesar 3,177 dengan nilai signifikan sebesar 0,002 < dari tingkat signifikan 0,05, dengan nilai koefisien sebesar 0,133 memiliki arah pengaruh positif. Hasil pengujian ini menunjukkan bahwa hipotesis pertama diterima yakni risk perception berpengaruh positif dan signifikan pada niat berinvestasi mahasiswa akuntansi. Hal ini berarti semakin tinggi risk perception maka semakin tinggi pula niat berinvestasi mahasiswa akuntansi. Hasil temuan ini sejalan dengan penelitian Warneryard (2001) yang menyebutkan bahwa individu yang memiliki persepsi risiko tinggi memiliki kemungkinan yang lebih besar untuk berinvestasi saham. Individu yang memiliki persepsi risiko tinggi memahami risiko masing-masing instrumen dan memiliki kemampuan untuk mengukur risiko sehingga mendorong niat untuk berinvestasi (Salisa, 2020).

Nilai koefisien regresi $X_{2}$ sejumlah $-0,215$ artinya jika gender mengalami peningkatan sejumlah satu satuan dengan asumsi risk perception maupun pengetahuan investasi dianggap tetap, maka niat melakukan investasi pada mahasiswa menurun sejumlah 0,215 . Hasil pengujian menunjukkan variabel gender memiliki t hitung sebesar -2,956 dengan nilai signifikan sebesar 0,003< dari tingkat signifikan 0,05 , dengan nilai koefisien sebesar $-0,215$ memiliki arah pengaruh negatif. Hasil pengujian ini menunjukkan bahwa hipotesis kedua diterima yakni gender berpengaruh negatif dan signifikan pada niat berinvestasi mahasiswa akuntansi. Hal ini berarti responden dengan jenis kelamin perempuan (0) memiliki niat semakin tinggi untuk berinvestasi, dan sebaliknya responden dengan jenis kelamin laki-laki (1) memiliki niat yang semakin rendah untuk berinvestasi. Hasil penelitian ini berbeda dengan temuan sebelumnya yang mengaitkan antara karakteristik perempuan yang mengindari risiko sehingga cenderung tidak melakukan kegiatan investasi atau mengalihkan ke instrumen lain yang memiliki risiko lebih rendah (Coleman, 2003). Hasil temuan mengungkapkan jika perempuan cenderung memiliki niat berinvestasi tinggi terutama pada instrumen aman seperti saham.

Nilai koefisien regresi $X_{3}$ sebesar 0,613 artinya jika pengetahuan investasi mengalami peningkatan sejumlah satu satuan dengan asumsi risk perception dan gender dianggap tetap, maka niat berinvestasi mahasiswa meningkat sejumlah 0,613 . Memperlihatkan variabel pengetahuan investasi mempunyai $t$ hitung sejumlah 11,695 bernilai signifikan sejumlah 0,000 < dari tingkat signifikan 0,05, dengan nilai koefisien sebesar 0,613 memiliki arah pengaruh positif. Hasil pengujian ini menunjukkan bahwa hipotesis ketiga diterima yakni pengetahuan investasi berpengaruh pada niat berinvestasi mahasiswa akuntansi. Semakin meningkat pengetahuan investasi memengaruhi atau meningkatkan niat 
berinvestasi pada mahasiswa akuntansi. Hasil temuan penelitian mendukung temuan penelitian sebelumnya yang mengemukakan bahwa pengetahuan investasi dapat meningkatkan niat berivestasi mahasiswa. Pengetahuan investasi dapat diperoleh melalui pelatihan investasi, seminar, maupun pelatihan pasar modal bagi mahasiswa sehingga mendorong niat berinvestasi (Tandio \& Widanaputra, 2016).

\section{SIMPULAN}

Berdasarkan hasil dan pembahasan penelitian, maka simpulan dari penelitian ini adalah risk perception, gender dan pengetahuan investasi menjadi variabel penentu niat berinvetasi mahasiswa akuntansi di Bali. Risk perception berpengaruh positif pada niat berinvestasi mahasiswa akuntansi. Artinya semakin tinggi risk perception berarti semakin tinggi niat berinvestasi mahasiswa akuntansi. Pada gender ditemukan pengaruh negatif dan signifikan pada niat berinvestasi mahasiswa akuntansi. Hal ini berarti responden perempuan memiliki niat yang semakin tinggi untuk berinvestasi, dan sebaliknya responden dengan laki-laki memiliki niat yang semakin rendah untuk berinvestasi. Pengetahuan investasi berpengaruh positif dan signifikan pada niat berinvestasi mahasiswa akuntansi. Artinya semakin tinggi pengetahuan terkait investasi, maka kian meningkatkan niat berinvestasi mahasiswa akuntansi.

Penelitian ini hanya terbatas menguji faktor personal dan sosial sebagai penentu niat berinvetasi mahasiswa akuntansi. Untuk memperoleh hasil yang konklusif, penelitian selanjutnya dapat mempetimbanga faktor lain seperti return yang diharapkan, adopsi teknologi dan ketersediaan sarana dan prasarana dalam pelaksanaan aktivitas investasi.

\section{REFERENSI}

Balai Pustaka. (1995). Kamus Besar Bahasa Indonesia. In Edisi Kedua. Jakarta: Depdikbud.

Bogan, V. L., Just., D. R., \& Dev., C. S. (2013). Team gender diversity and investment decision-making behavior. Review of Behavioral Finance, 2(2), 134152.

Coleman, S. (2003). Women and Risk: An Analysis of Attitudes and Investment Behavior. Academy of Accounting and Financial Studies Journal, 7(2), 99-114.

Dewi, N. N. S. R. T., Adnantara, K. F., \& Asana, G. H. S. (2017). Modal Investasi Awal Dan Persepsi Risiko Dalam Keputusan Berinvestasi. Jurnal Ilmiah Akuntansi, 2(2), 173-190.

Dina, N. (2009). Gender Dan Risk Attitude Dalam Pemilihan Portofolio Investasi Pada Asset Beresiko: Studi Eksperimental.

Fishbein, M., \& Ajzen, I. (1991). The Influence of Attitudes on Behavior. The Handbook of Attitudes, 173-222. https:/ / doi.org/10.1016/0749-5978(91)90020$\mathrm{T}$

Halim, A. (2005). Analisis Investasi. Salemba Empat, Jakarta.

Hamonangan, D. (2007). Pengaruh Pengetahuan Investasi Mahasiswa Jurusan Akuntansi Terhadap Minat Untuk Berinvestasi Pada Pasar Modal di Kota Palembang. Jurnal Keuangan Dan Bisnis, 5(2), 136-147.

Hartono, J. (2010). Teori Portofolio dan Analisis Investasi. BPFE-Yogyakarta. 
Hurlock, E. . (1999). Psikologi Perkembangan: Suatu Pendekatan Sepanjang Rentang Kehidupan. In Alih bahasa: Istiwidayati \& Soedjarwo. Edisi Kelima. Jakarta: Erlangga.

Kusmawati. (2011). Pengaruh Motivasi Terhadap Minat Berinvestasi di Pasar Modal dengan Pemahaman Investasi dan Usia Sebagai Variabel Moderat. Jurnal Ekonomi Dan Informasi Akuntansi, 1(Mei), 103-117.

Mokhtar, A. I. (2014). Behavioral Finance, Investor Psychology Perspective. Journal of Finance and Investment Analysis, 3(2), 41-60.

Nurhidayah. (2016). Gender, Pengetahuan Keuangan, dan Niat Bertansaksi Saham. Jurnal Ilmiah Bisnis Dan Ekonomi Asia, 12(2), 07-15. https://doi.org/10.32812/jibeka.v12i2

Pompian, M. M., \& Longo, J. M. (2004). A New Paradigm for Practical Application of Behavioral Finance: Creating Investment ProgramsBased on Personality Type and Gender to Produce Better Investment Outcomes. The Journal of Wealth Management, 7(2), 9-15. https://doi.org/10.3905/jwm.2004.434561

Prosad, J. M., Kapoor, S., \& Sengupta, J. (2015). Behavioral biases of Indian investors: a survey of Delhi-NCR region. Qualitative Research in Financial Markets, 7(3), 230-263. https://doi.org/10.1108/QRFM-04-2014-0012

Salisa, N. R. (2020). Faktor yang Mempengaruhi Minat Investasi Di Pasar Modal: Pendekatan Theory Of Planned Behaviour (TPB). Jurnal Akuntansi Indonesia, 9(2), 182-194.

Sriatun, \& Indarto. (2017). Perilaku Investasi Sektor Keuangan Di Kalangan Pegawai Negeri Sipil: Pengembangan Theory Planned Of Behavior. Jurnal Riset Ekonomi Dan Bisnis, 10(3), 28-47. https://journals.usm.ac.id/index.php/jreb/article/view/880

Tandio, T., \& Widanaputra, A. A. G. P. (2016). Engaruh Pelatihan Pasar Modal, Return, Persepsi Risiko, Gender, Dan Kemajuan Teknologi Pada Minat Investasi Mahasiswa. E-Jurnal Akuntansi Universitas Udayana, 16(3), 23162341. https://ojs.unud.ac.id/index.php/Akuntansi/article/view/21199

Tauni, M. Z., Rao, Z.-R., Fang, H., Mirza, S. S., Memon, Z. A., \& Jebran, K. (2017). Do investor's Big Five personality traits influence the association between information acquisition and stock trading behavior? China Finance Review International, 7(4), 450- 477. https:/ / doi.org/10.1108/CFRI-06-2016-0059

Weber, E. U., Blais, A.-R., \& Betz, N. E. (2002). A Domain-Specific Risk-Attitude Scale: Measuring Risk Perceptions And Risk Behaviors. Journal Of Behavioral Decision Making, 15(4). https:/ / doi.org/10.1002/bdm.414

Weston, J. F., \& Copeland, T. E. (1995). Manajemen Keuangan. In Edisi ke 9. Jakarta: Binarupa Aksara.

Winkel, W. . (1983). Psikologi Pengajaran. Jakarta: PT. Gramedia Widia Sarana Indonesia.

Wiwin. (2006). Pengaruh Pengetahuan Investasi dan Tipe Investor Terhadap Minat Mahasiswa STIE Musi Palembang Jurusan Akuntansi Untuk Berinvestasi Pada Investasi Keuangan. STIE Musi Palembang.

Yuwono, S. R. (2011). Pengaruh Karakteristik Investor Terhadap Besaran Minat Investasi Saham di Pasar Modal. Program Studi Magister Manajemen Universitas Indonesia. 